\title{
Effect of Particle Impact Angle, Erodent Particle Size and Acceleration Pressure on the Solid Particle Erosion Behavior of 3003 Aluminum Alloy
}

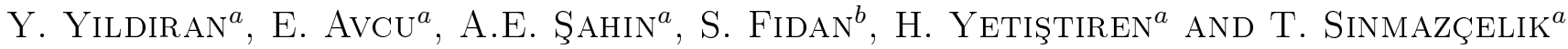 \\ ${ }^{a}$ Kocaeli University, Mechanical Engineering Department, Umuttepe Campus, 41380 Izmit, Turkey \\ ${ }^{b}$ Kocaeli University, School of Civil Aviation, Arslanbey Campus, 41285 Izmit, Turkey
}

\begin{abstract}
This study aims to examine solid particle erosion behavior of 3003 aluminum alloy. 3003 aluminum alloy samples were eroded in erosion test rig under various particle impingement angles $\left(15^{\circ}, 30^{\circ}, 45^{\circ}\right.$ and $\left.60^{\circ}\right)$ and acceleration pressures (1.5, 3 and 4 bar) by using 80 mesh and 180 mesh sized erodent particles (garnet). The erosion rates of aluminum alloy samples were calculated depending on the erosion parameters. The erosion rates of the samples have varied dramatically depending on particle impingement angle, acceleration pressure and erodent particle size. The maximum erosion rates were observed at $15^{\circ}$ impingement angles at all acceleration pressures and particle sizes. Moreover, erosion rates of the samples were increased with increases in acceleration pressure at all particle impingement angles and particle sizes. On the other hand, erosion rates of the samples decrease with increase in erodent particle sizes. Hence, maximum erosion was observed when the aluminum alloy eroded at $15^{\circ}$ impingement angle and 4 bar pressure by using 180 mesh erodent particles. Finally, the eroded surfaces of the samples were analyzed by using scanning electron microscope. The surfaces of the samples were also investigated by using energy dispersive X-ray analysis in scanning electron microscopy studies. Microcutting and microploughing erosion mechanisms were observed at $15^{\circ}$ and $30^{\circ}$ impingement angles, while deep cavities and valleys formed due to plastic deformation were observed at $45^{\circ}$ and $60^{\circ}$ impingement angles. Moreover, embedded erodent particles were clearly detected on the surfaces of the samples by energy dispersive X-ray analysis.
\end{abstract}

DOI: $10.12693 /$ APhysPolA.125.523

PACS: 81.05.Bx, 81.70.-q, 68.35.B-, 68.35.-p, 42.79.Ls, 68.37.Hk, 07.85.Nc

\section{Introduction}

3003 aluminum alloys have been widely used in many engineering fields due to its relatively low cost, high strength to weight ratio, and high corrosion resistance. They have been replacing conventional materials specifically in automotive industry due to their superior specific properties [1-4]. Solid particle erosion is a process which occurs by progressive removal of material from surfaces of the target material due to repeated impact of erodent particles [5-7]. It has been reported that solid particle erosion causes to damages in various engineering applications specifically in aircraft applications. However, it has been reported that it also plays an important role in automotive applications [8].

Solid particle erosion is a complex process which is affected by many parameters. In literature, researchers have reported that operational parameters such as particle impingement angle, velocity and particle size plays a crucial role on the solid particle erosion behavior of materials [5-7]. Hence, in this study solid particle erosion behavior of 3003 aluminum alloy have been investigated depending on particle impingement angle, acceleration pressure, and erodent particle size. It is aimed to examine the effects of these parameters on the solid particle erosion behavior of aluminum alloys.

\section{Materials and methods}

3003 aluminum alloy used in this study was supplied by ASSAN Alüminyum (Aluminum Company, Turkey) in the form of $300 \times 200 \mathrm{~mm}^{2}$ sheets (thickness of $3 \mathrm{~mm}$ ). The samples were cut to sheets of $40 \times 40 \mathrm{~mm}^{2}$ by us- ing a guillotine shear. Chemical composition, mechanical and physical properties of 3003 alloy samples are given in Table I.

TABLE I

Chemical composition, mechanical and physical properties of 3003 samples.

\begin{tabular}{c|c}
\hline \hline Aluminum alloy & $3003 \mathrm{H} 14$ \\
\hline BS EN 485-2:2004 & $\begin{array}{c}\text { Alloy EN AW-3003 } \\
\text { [Al Mn1Cu] }\end{array}$ \\
\hline \multicolumn{2}{c}{ Chemical composition (max. values) [wt\%] } \\
Cr 0.05, Zn 0.10, Ti 0.050 \\
\hline \multicolumn{2}{c}{ Mechanical properties } \\
\hline tensile strength ultimate & $152 \mathrm{MPa}$ \\
tensile strength yield & $145 \mathrm{MPa}$ \\
modulus of elasticity & $68.9 \mathrm{GPa}$ \\
hardness brinell & 40 \\
\hline \multicolumn{2}{c}{ Physical properties } \\
\hline density & $2.73 \mathrm{~g} / \mathrm{cm}^{3}$
\end{tabular}

The erosion test rig used in this study is illustrated in Fig. 1. SEM photos of garnet particles used in this study are given in Fig. 2. Accelerated particles impacted the specimen, which can be hold at various impingement angles $\left(15^{\circ}-60^{\circ}\right)$ by adjustable sample holder shown in Fig. 1. Solid particle erosion test parameters are given in Table II.

Moreover, to characterize the morphology of eroded surfaces and to understand material removing mecha- 


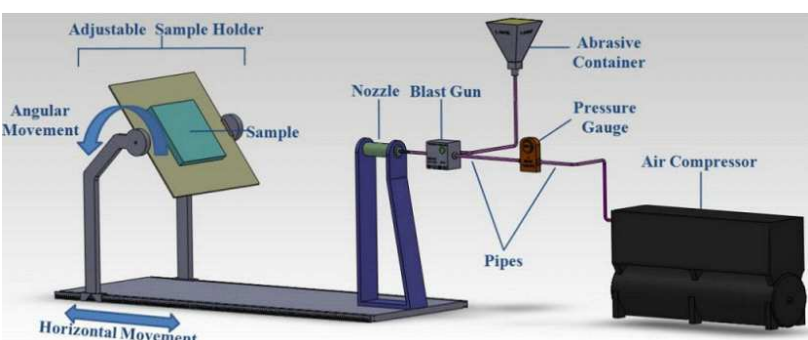

Fig. 1. Solid particle erosion test rig.

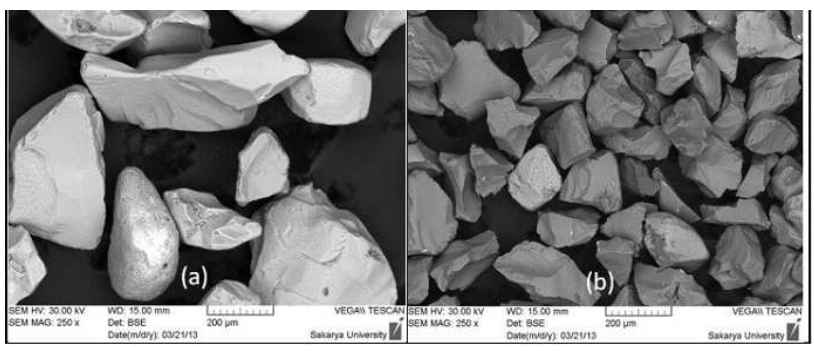

Fig. 2. SEM photos of erodent particles (a) 80 mesh, (b) 180 mesh.

nism, eroded surfaces of 3003 samples were examined by using scanning electron microscope (Tescan Vega2).

\section{Results and discussion}

In Fig. 3, the erosion rates of the aluminum alloy depending on the particle impingement angle and acceleration pressure were given. It was clearly seen that both particle impingement angle and acceleration pressure play a crucial role in the solid particle erosion behavior of aluminum alloy. The maximum erosion rate was observed at $15^{\circ}$ impingement angle at all acceleration pressures. The erosion rate of the aluminum alloy was decreased with increases in particle impingement angle. On the other hand, erosion rate was increased with augmentation in acceleration pressure. The increase of the acceleration pressure causes to increase the impingement velocities of the erodent particles. As a result, at higher acceleration pressure erodent particles impact to the target material at higher velocities and the increase of the erosion rate is understandable due to high impact energies of the particles at higher velocities.

In Fig. 4, the variation of the erosion rates of 3003 aluminum alloy depending on the erodent particles size

Test parameters.

TABLE II

\begin{tabular}{c|c}
\hline \hline erodent type & garnet \\
erodent size & 80 mesh, 180 mesh \\
particle impingement angle & $15^{\circ}, 30^{\circ}, 45^{\circ}, 60^{\circ}$ \\
acceleration/blast gun pressure & $1.5 \mathrm{bar}, 3 \mathrm{bar}, 4 \mathrm{bar}$ \\
test temperature & $25^{\circ} \mathrm{C}$ \\
nozzle diameter & $5 \mathrm{~mm}$ \\
nozzle length & $50 \mathrm{~mm}$
\end{tabular}

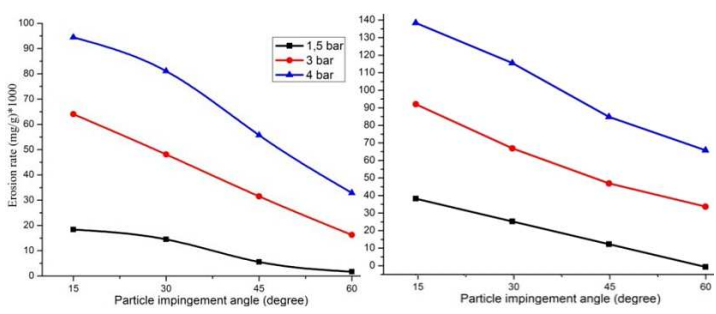

Fig. 3. The variation of erosion rates of 3003 aluminum alloy depending on particle impingement angle and acceleration pressure: (a) 80 mesh, (b) 180 mesh.

was given. The erosion rates of the samples were decreased by the increase of the erodent particles size. The maximum erosion was observed when the aluminum alloy was eroded by using smaller erodent particles at all impingement angles and acceleration pressures. It can be concluded that smaller erodent particles can erode the aluminum alloy more efficiently compared to larger erodent particles.

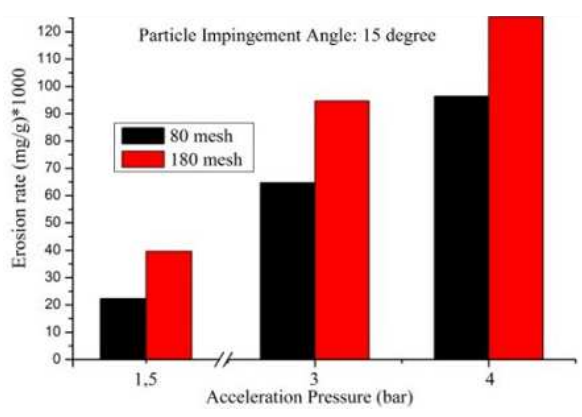

Fig. 4. The variation of the erosion rates of 3003 aluminum alloy depending on erodent particle size.

SEM photos and EDS analysis of the eroded surfaces of the samples were given in Fig. 5. Materials which show ductile erosion behavior can be easily worn off by microcutting and microploughing erosion mechanisms caused by the lateral impact of the particles. On the other hand, normal impact of the particles are intensely caused to plastic deformation, however removal of material from the surfaces of ductile materials is not efficient by the normal impact of the particles.

In Fig. $5 \mathrm{a}-\mathrm{c}$ at $15^{\circ}$ impingement angle microcutting and microploughing erosion mechanisms were clearly seen, while deep cavities and valleys caused by the plastic deformation were observed at $60^{\circ}$ impingement angle in Fig. 5b. As a result, aluminum alloy was severely damaged at $15^{\circ}$ impingement angles and slightly damaged at $60^{\circ}$ impingement angle due to mentioned erosion mechanisms. As seen in Fig. 5, acceleration pressure and erodent particle size did not affect the observed erosion mechanisms. However, these parameters affected the scale of the erosion damage. Increase of the acceleration pressure was caused to increase the erosion damage on the surfaces, while the erosion damage on the surface was 


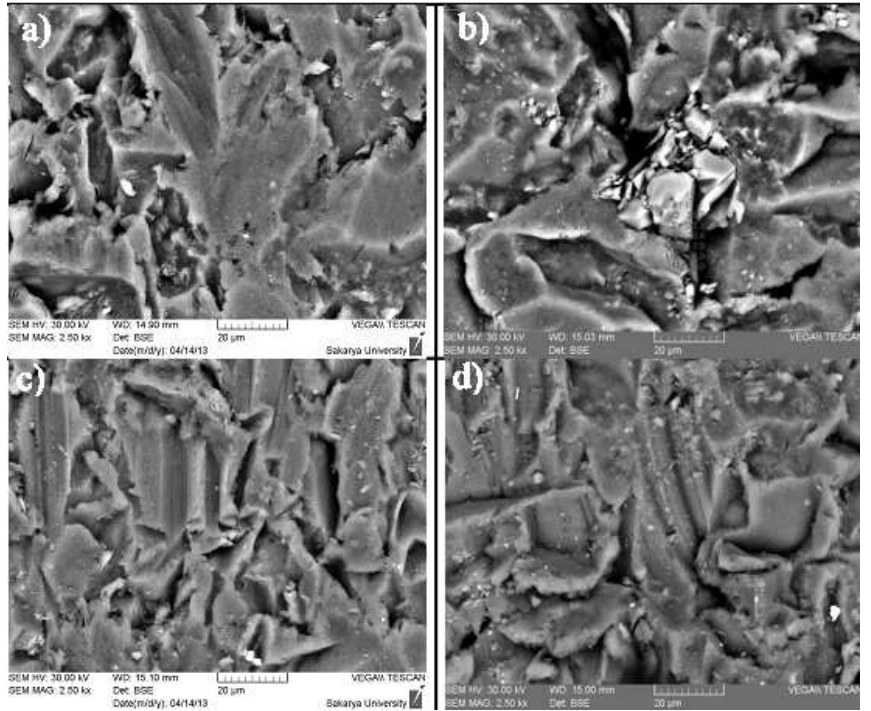

Fig. 5. SEM photos and EDS analysis of the eroded surfaces of the samples: (a) 1.5 bar, $15^{\circ}, 80$ mesh, (b) 1.5 bar, $60^{\circ}, 80$ mesh, (c) 1.5 bar, $15^{\circ}, 180$ mesh, (d) 4 bar, $15^{\circ}, 180$ mesh.

decreased with the increase of the particle size. Hence, it can be said that the surface morphology of the samples was perfectly correlated with the erosion rate results of the samples. Finally, in Fig. 5b and d EDS analysis of the eroded surfaces of the sample was given. The existence of the $\mathrm{O}$ and $\mathrm{Fe}$ atoms in high percentage was the evidence of the embedded erodent garnet particles to the surfaces of the samples. Based upon the EDS analysis results, it was concluded that the erodent particles were embedded to the surfaces of the aluminum alloy during the erosion process. It was concluded that this can be possible because of the ductile behavior of the aluminum alloy.

\section{Conclusions}

In this study, particle impingement angle, velocity and erodent particle size effects on the solid particle erosion behavior of 3003 aluminum alloy have been investigated. The conclusions of the study are given below.

1. The erosion rate of the 3003 aluminum alloy was increased with increases in acceleration pressure, while it was decreased with increases in erodent particle size. On the other hand, maximum erosion was observed at $15^{\circ}$ impingement angle and the minimum erosion was observed at $60^{\circ}$ impingement angle.

2. At $15^{\circ}$ impingement angle, microploughing and microcutting were observed as dominant erosion mechanism. At $60^{\circ}$ impingement angle plastic deformations were observed as dominant erosion mechanisms. Acceleration pressure and erodent particle size did not affect the observed erosion mechanisms. However, these parameters affected the scale of the erosion damage.

3. EDS analysis revealed that erodent particles can be embedded on the surfaces of the samples during the erosion process due to ductility of the 3003 aluminum alloy.

\section{Acknowledgments}

The authors acknowledge sincere gratitude to research assistant M.Sc. Material Engineer Fatih Erdem Baştan and other members of the Sakarya University Thermal Spray Center for providing assistance during SEM studies. Also, the authors thank to M.Sc. Material Engineer Onur Birbaşar and other member of the R\&D department of ASSAN Alüminyum company for their support.

\section{References}

[1] Y. Liu, G.Z. Meng, Y.F. Cheng, Electrochim. Acta 54, 4155 (2009).

[2] G.A. Zhang, L.Y. Xu, Y.F. Cheng, Corrosion Sci. 51, 283 (2009).

[3] H.W. Huang, B.L. Ou, Mater. Des. 30, 2685 (2009).

[4] J. Zander, R. Sandström, Mater. Des. 30, 3752 (2009).

[5] A.F. Yetim, F. Yildiz, Y. Vangolu, A. Alsaran, A. Celik, Wear 267, 2179 (2009).

[6] E. Avcu, S. Fidan, S. Karabay, T. Sinmazçelik, J. Fac. Eng. Archit. Gaz. 27, 865 (2012).

[7] E. Avcu, S. Fidan, M.Ö. Bora, O. Çoban, İ. Taşkiran, T. Sinmazçelik, Adv. Polym. Technol. 32, 386 (2013).

[8] M.A. Verspui, G. de With, A. Corbijn, P.J. Slikkerveer, Wear 233-235, 436 (1999). 